\title{
Kajian Komposisi Jalur Hijau Jalan di Kota Yogyakarta Terhadap Penjerapan Polutan Timbal (Pb)
}

DOI 10.18196/pt.2014.027.81-89

\author{
Fadlhinsyah Damanik \\ Goodhope Asia Holdings Ltd. Menara Global Building 16th Floor, Unit C - D, \\ JI. Jend. Gatot Subroto Kav. 27 Jakarta, 12950, Indonesia, Tel: 622152892260 - 61, Fax: 622152892259 , \\ email: fadlhinsyah.damanik@gmail.com
}

\begin{abstract}
ABSTRAK
Penelitian ini bertujuan mengkaji komposisi jalur hijau jalan dan kemampuannya dalam menjerap (adsorpsi) partikel timbal (Pb), mengetahui jumlah emisi partikel Pb pada udara ambien yang dihasilkan dari aktivitas lalu lintas kendaraan bermotor, dan mengevaluasi komposisi jalur hijau pada beberapa ruas jalan. Penelitian dilakukan dengan menggunakan Metode Survey, yang teknis pelaksanaannya dilakukan dengan observasi, kuisioner dan pengumpulan data sekunder. Pengambilan sampel dilakukan dengan Purposive sampling yanitu pemilihan sampel dengan pertimbangan tertentu yang dianggap relevan dan sesuai dengan tujuan penelitian. Data yang diperoleh dianalisis secara deskriptif. Hasil penelitian menunjukkan bahwa jalur hijau di ketiga ruas jalan didominasi oleh pohon Angsana (Pterocarpus indicus) dalam bentuk menjalur 1 baris tanaman. Jalur hijau baik jenis, jumlah, fungsi, ukuran, serta sebaran tanaman yang tersedia belum mampu menurunkan konsentrasi timbal (Pb) sehingga diperlukan penataan ulang. Jalan yang ditanami pohon Angsana (Pterocarpus indicus)

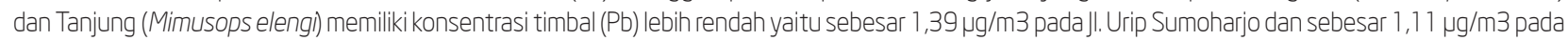
J. Laksada Adisucipto dibanding dengan jalan yang hanya ditanami pohon Angsana (Pterocarpus indicus) yaitu Jl. KH. Ahmad Dahlan dengan konsentrasi Pb sebesar 1,56 $\mathrm{\mu g} / \mathrm{m3}$. Konsentrasi timbal (Pb) di ketiga ruas jualan sudah mendekati nilai ambang batas, tetapi masih di bawah baku mutu yang ditentukan. Kata kunci: Jalur hijau jalan, Jerapan Timbal (Pb), Model tata hijau
\end{abstract}

\begin{abstract}
This research aims to examine the composition of the green belt and its ability to adsorb particles of lead (Pb), determine the amount of particulate emissions of lead in the ambient air resulting from vehicle traffic activities and evaluate the composition of green belt some streets. The research was conducted using a survey method, the technical implementation is done by observation, questionnaires and secondary data collection. Sampling was done by purposive sampling is the selection of the sample with certain considerations deemed relevant according to the research objectives. Data were analyzed descriptively. The result showed that the green belt in three streets was dominated by Angsana trees (Pterocarpus indicus) form a line 1 (one) row crops. The composition of the green belt type, quantity, function, size, and distribution of plants available have not been able to reduce the concentration of lead (Pb) and thus require rearrangement. The roads planted with tree of Angsana (Pterocarpus indicus) and Tanjung (Mimusops elengi) had concentrations of lead (Pb) lower, as much as 1,39 $\mathrm{\mu g} / \mathrm{m} 3$ at Urip Sumoharjo and as much as $1,11 \mu \mathrm{g} / \mathrm{m} 3$ at Laksda Adisucipto compared the road that only planted tree of Angsana (Pterocarpus indicus) is contained at Ahmad Dahlan with (Pb) concentration as much as 1,56 $\mu \mathrm{g} / \mathrm{m} 3$. Concentrations of lead (Pb) in the third road was approaching the threshold value, but still below the quality standards specified. Keywords: Green belt composition, Timbales (Pb) adsorption, Model of green belt
\end{abstract}

\section{PENDAHULUAN}

Penelitian dilaksanakan pada bulan Oktober sampai dengan Desember 2013 di tiga ruas jalan yaitu: Jl. KH. Ahmad Dahlan, Jl. Urip Sumoharjo dan Jl. Laksda Adisucipto Kota Yogyakarta. Secara administratif Jl. KH. Ahmad Dahlan masuk ke dalam wilayah Kecamatan Gondomanan sedangkan Jl. Urip Sumoharjo dan Jl. Laksda Adisucipto berada pada wilayah Kecamatan Gondokusuman.

Bahan yang digunakan dalam penelitian ini adalah kondisi eksisting jalur hijau dan peta jalan Kota Yogyakarta baik hasil survei langsung maupun data dari instansi terkait. Alat yang digunakan meliputi: alat tulis, kamera dan perangkat komputer. Selanjutnya data dikumpulkan untuk dianalisis.

Penelitian ini menggunakan metode survey. Data yang digunakan dalam penelitian ini yakni data primer dan data sekunder. Tiga titik lokasi dipilih sebagai acuan dari 10 titik lokasi pemantauan kualitas udara ambien oleh BLH Kota Yogyakarta. Adapun lokasi pemantauan 
yang dipilih sebagai berikut: Perempatan Kantor Pos Pusat, merupakan kawasan yang berhubungan langsung dengan Jl. KH. Ahmad Dahlan, Perempatan Galleria Mall,merupakan kawasan yang berhubungan langsung dengan Jl. Urip Sumoharjo dan Depan Hotel Saphir: Lokasi hotel berada pada kawasan Jl. Laksda Adisucipto. Pemilihan lokasi dilakukan berdasarkan eksisting jalur jalan dan keberadaan jalur hijau jalan. Selain itu, pemilihan lokasi juga dilakukan atas dasar kualitas udara ambien, yaitu 3 ruas jalan yang dipilih merupakan jalan yang mempunyai tingkat polusi udara tinggi terutama partikel timbal $(\mathrm{Pb})$ dibanding dengan jalan lainnya di Kota Yogyakarta.

Teknik pengambilan sampel dilakukan dengan metode Non-Probality sampling dan Purposive sampling (purposif sampel). Masyarakat yang dijadikan sampel tidak direncanakan terlebih dahulu tetapi dapat dijumpai secara tiba-tiba (Matra, 2012). Sampel yang digunakan tidak didasarkan pada jumlah populasi manusia maupun populasi kendaraan bermotor pada suatu kawasan, tetapi didasarkan pada pendugaan kepadatan lalu lintas kendaraan bermotor. Penggunaan sampel $\geq 30$ (sampel besar) diharapkan dapat mewakili sifat populasi secara keseluruhan. Total sampel atau responden yang digunakan adalah 150 orang. Selanjutnya data-data yang terkumpul dianalisis secara deskriptif.

\section{HASIL DAN PEMBAHASAN}

Kondisi Fisik

Di antara 14 kecamatan di Kota Yogyakarta, Kecamatan Gondomanan merupakan kecamatan terkecil ke-4 berdasar luas wilayahnya. Luas wilayah Kecamatan Gondomanan adalah 1,12 $\mathrm{Km}^{2}$ atau sebesar 3,4\% dari total luas wilayah Kota Yogyakarta. Wilayah Kota Yogyakarta seluas $42 \mathrm{Ha}$ berada pada ketinggian < 100 dan 70 Ha berada pada ketinggian 100-199 mdpl. Ke- camatan Gondomanan terletak di jantung Kota Yogyakarta berdampingan dengan Kecamatan Pakualaman. Penggunaan lahan di wilayah Kecamatan Gondomanan untuk perumahan seluas 46,47 hektar; jasa 29,56 hektar; perusahaan 22,64 hektar; industri 1,52 hektar dan lainlain 11,81 hektar (BPS Kota Yogyakarta, 2013). Sementara Kecamatan Gondokusuman secara proposional merupakan wilayah kecamatan terbesar ke-2 setelah Kecamatan Umbulharjo. Kecamatan Gondokusuman berbatasan dengan kabupaten Sleman. Penggunaan lahan di Kecamatan Gondomanan untuk perumahan seluas 224,38 hektar; jasa seluas 69,25,; perusahaan 61,96 hektar; industri 6,34 hektar; pertanian 0,03 hektar; daerah non-produktif- seluas 0,42 hektar dan lain-lain seluas 36,63 hektar (BPS Kota Yogyakarta, 2013). Berdasar Keputusan Walikota Yogyakarta No. 619 tahun 2007 tentang Rencana Aksi Daerah dan Peningkatan Kualitas Lingkungan Kota Yogyakarta tahun 2007-2011, luas Jalan KH. Ahmad Dahlan adalah seluas 14.025 $\mathrm{m}^{2}$, untuk jalur hijau seluas $14.275 \mathrm{~m}^{2}$ dan taman seluas $250 \mathrm{~m}^{2}$. Luas Jalan Urip Sumoharjo adalah 14.871,6 $\mathrm{m}^{2}$, jalur hijau 15.171,6 $\mathrm{m}^{2}$ dan memiliki taman seluas $300 \mathrm{~m}^{2}$, sedangkan Jalan Laksda Adisucipto seluas $5.796 \mathrm{~m}^{2}$, luas jalur hijau $6.045 \mathrm{~m}^{2}$ dan memiliki taman seluas 249 $\mathrm{m}^{2}$. Akan tetapi dari luas keseluruhan jalur hijau di masing-masing ruas jalan belum memberikan manfaat yang berarti. Sebaliknya, nilai-nilai fungsional jalur hijau tersedia semakin menurun yang ditandai dengan meningkatnya pencemaran udara khususnya partikel timbal $(\mathrm{Pb})$.

\section{Pencemaran Timbal}

Jumlah kendaraan bermotor di Kota Yogyakarta tahun 2003 sebanyak 240.897 (BLH Kota Yogyakarta, 2013), dan jumlah kendaraan bermotor di Kota Yogyakarta tahun 2012 sebanyak 372.222 (SLHD Kota Yogyakarta, 2012). Dari 
data tersebut, dapat diasumsikan bahwa pertumbuhan jumlah kendaraan bermotor dalam angka tahun 2003 sampai dengan tahun 2012 sebanyak 131.325 unit kendaraan bermotor di Kota Yogyakarta. Hasil dari meningkatnya jumlah kendaraan bermotor tentu akan berdampak terhadap Peningkatan pencemaran udara terutama konsentrat timbal $(\mathrm{Pb})$ Tabel 1).

Tabel 1. Hasil Pemantauan Konsentrat Pb di Udara

\begin{tabular}{lccc}
\hline & \multirow{2}{*}{ Lokasi } & Baku & Hasil Analisa Pb/jam dalam Tahun $(\mu \mathrm{g} / \mathrm{m} 3)$ \\
\cline { 3 - 4 } \cline { 3 - 4 } & & 2012 & 2013 \\
\hline Putu Pbempatan Kantor Pos Pusat & & 1,54 & 1,56 \\
Perempatan Galleria Mall & $2 \mu \mathrm{g} / \mathrm{m} 3$ & 1,33 & 1,39 \\
Depan Hotel Saphir & & 1,06 & 1,11 \\
\hline
\end{tabular}

\section{Komposisi Jalur Jalan Hijau}

Menurut Baiti (2012), Jalur Hijau merupakan salah satu jenis RTH dengan persentase paling besar di wilayah Kota Yogyakarta, yaitu sebesar $11,09 \%$ atau 360,44 hektar dari 17,17 \% atau 557,72 hektar. Luas RTH Kota Yogyakarta tergolong rendah. Optimalnya RTH perkotaan adalah $30 \%$ dari luas wilayah kota. Adapun jenis dan jumlah pohon yang mengisi jalur hijau di tiga ruas jalan adalah sebagai berikut:

\section{Jl. KH. Ahmad Dahlan}

Jl. KH. Ahmad Dahlan memiliki luas jalan sebesar $14.025 \mathrm{~m} 2$. Jalan ini menerapkan sistem jalur dua arah dan memiliki jalur hijau pada kedua sisi tepi jalan dalam bentuk menjalur 1 baris. Jenis dan jumlah pohon yang mengisi jalur hijau Jl. KH. Ahmad Dahlan disajikan pada Tabel 2.

Tabel 2. Jenis dan Jumlah Pohon Jl. KH.Ahmad Dahlan

\begin{tabular}{lccc}
\hline Nama Tanaman & Nama Ilmiah & Jumlah & Persentase (\%) \\
\hline Angsana & Pterocarpus indicus & 72 & 82,75 \\
Beringin & Ficus benjamina & 6 & 6,89 \\
Kersen/Talok & Muntingia calabura & 6 & 6,89 \\
Ketapang & Terminalia catapa L. & 3 & 3,44 \\
\hline
\end{tabular}

Jarak tanam yang digunakan adalah 5 meter dengan penempatan tanaman sekitar 0,5 - 2 meter dari bahu jalan. Komponen pohon pengisi jalur hijau Jl. KH. Ahmad Dahlan didominasi oleh pohon Angsana (Pterocarpus indicus) yang berukuran besar. Luas tajuk rata-rata pohon Angsana pada jalan ini adalah 8 meter, ketinggian $\geq 8$ meter dan memiliki diameter batang bawah $\pm 40 \mathrm{~cm}$. Pohon Angsana merupakan salah satu jenis tanaman yang sering digunakan sebagai pengisi jalur hijau untuk mengatasi pencemaran udara. Berdasarkan penelitian Samsoedin (2010), akumulasi timbal $(\mathrm{Pb})$ pada kulit batang tanaman Angsana (Pterocarpus indicus) lebih banyak dibanding dengan kulit batang tanaman Glodokan Tiang (Polyalthia longifolia) di beberapa tempat di kota Makassar. Agnesia (2010) cit. Yulfida (2012), menyebutkan bahwa kandungan timbal $(\mathrm{Pb})$ yang terdapat pada daun Angsana (Pterocarpus indicus) lebih tinggi dibandingkan dengan kandungan timbal $(\mathrm{Pb})$ pada daun Glodongan (Polyalthia indicus). Hal tersebut menggambarkan bahwa pohon Angsana (Pterocarpus indicus) mempunyai kemampuan yang lebih baik dalam menyerap polutan timbal $(\mathrm{Pb})$ dibandingkan pohon Glodongan (Polyalthia indicus) yang terdapat di jalan raya di kota Medan. Jenis pohon lainnya yang terdapat pada Jl. KH. Ahmad Dahlan adalah Beringin (Ficus benjamina), Kersen (Muntingia calabura) dan Ketapang (Terminalia catappa L). Tiga jenis pohon ini tergolong berukuran sedang dengan luas tajuk rata-rata 5 meter. Penggunaan pohon Beringin, Kersen dan Ketapang pada jalan ini adalah sebagai perindang lahan parkir yang lokasinya berada pada trotoar jalan.

\section{Jl. Urip Sumoharjo}

Jl. Urip Sumoharjo merupakan jalan yang menerapkan sistem jalur jalan satu arah. Jalan 
ini memiliki luas jalan 14.871,6 $\mathrm{m}^{2}$ dan jalur hijau ditempatkan pada kedua sisi tepi jalan dalam bentuk menjalur 1 baris. Jenis dan jumlah pohon pada jalan ini disajikan pada Tabel 3 .

Tabel 3. Jenis dan Jumlah Pohon Jl. Urip Sumoharjo

\begin{tabular}{lccc}
\hline Nama Tanaman & Nama Ilmiah & Jumlah & Persentase (\%) \\
\hline Angsana & Pterocarpus indicus & 43 & 45,26 \\
Asem landi & Pitchecolobium dulce & 3 & 3,15 \\
Beringin & Ficus benjamina L & 3 & 3,15 \\
Biola cantik & Ficus lyrata & 3 & 3,15 \\
Kiara paying & Filicium decipiens & 4 & 4,21 \\
Tanjung & Mimusops elengi & 35 & 36,84 \\
Waru & Hibiscus tiliaceus & 4 & 4,21 \\
\hline
\end{tabular}

Dari tujuh jenis pohon yang terdapat pada Jalan Urip Sumoharjo, pohon Angsana (Pterocarpus indicus) merupakan jenis pohon yang paling mendominasi diikuti oleh pohon Tanjung (Pterocarpus indicus). Luas tajuk rata-rata pohon Angsana pada jalan ini adalah 6 meter sedangkan luas tajuk pohon Tanjung adalah 5 meter. Kedua jenis pohon ini memiliki manfaat yang sama yaitu sebagai tanaman anti polutan. Hasil penelitian menyebutkan bahwa pohon Tanjung memiliki ketahanan tinggi terhadap pencemaran debu semen dan kemampuan yang tinggi dalam menjerap (adsorbsi) dan menyerap (absorbsi) debu semen. Selain itu tanaman mahoni, kenari, meranti merah, kiara payung dan kayu hitam juga memiliki kemampuan yang sama (Departemen Pekerjaan Umum, 2006). Pohon Tanjung juga memiliki kerapatan daun lebih tinggi jika dibanding dengan tanaman lain yang ada pada Jl. Urip Sumoharjo. ini menunjukkan bahwa pohon Tanjung pada Jl. Urip Sumoharjo juga digunakan sebagai peredam kebisingan. Hasil pengukuran Hidayat (2008) cit. Rizka (2009), menunjukkan bahwa kerapatan daun berperan penting dalam meredam kebisingan. Manfaat lain pohon Tanjung adalah aroma wangi yang di- hasilkan bunganya dapat menetralisir bau tidak sedap seperti bau dari hasil tumpukan sampah, limbah dan lain sebagainya. Rata-rata pohon berukuran sedang berdiameter batang $\leq 30 \mathrm{~cm}$, jarak tanam 9 meter dan ditanam 0,5-1,5 meter dari bahu jalan.

\section{Jl. Laksda Adisucipto}

Jalur hijau Jl. Laksda Adisucipto sedikit berbeda dari dua jalan lainnya. Jalur hijau pada jalan ini ditempatkan pada 3 (tiga) titik yaitu pada tepi kiri dan tepi kanan jalan serta pada bagian median jalan dalam bentuk menjalur 1 baris tanaman. Jl. Laksda Adisucipto adalah jalan yang menggunakan jalur jalan dua arah dan memiliki luas jalan $5.796 \mathrm{~m}^{2}$. Jenis dan jumlah pohon yang terdapat pada jalan ini disajikan pada Tabel 4.

Tabel 4. Jenis dan Jumlah Pohon Jl. Laksda Adisucipto

\begin{tabular}{lccc}
\hline Nama Tanaman & Nama Ilmiah & Jumlah & Persentase (\%) \\
\hline Angsana & Pterocarpus indicus & 65 & 82,27 \\
Beringin & Ficus benjamina & 4 & 5,06 \\
Tanjung & Mimusops elengi & 10 & 12,65 \\
\hline
\end{tabular}

Kesamaan jalur hijau Jl. Laksda Adisucipto dengan jalur hijau dua jalan lainnya adalah, jalur hijau lebih didominasi oleh pohon Angsana (Pterocarpus indicus). Pada Jl. Laksda Adisucipto, median jalan merupakan bagian yang memiliki populasi pohon Angsana paling tinggi. Pohon Angsana pada bagian ini tergolong berukuran kecil dengan massa daun dan bentuk percabangan yang belum menutup sempurna. Luas tajuk pohon Angsana adalah 3 meter dan tinggi tanaman $\leq 6$ meter dengan jarak tanam yang digunakan adalah 5 meter. Pada bagian tepian jalan, populasi pohon sangat minim dengan diisi sedikit pohon Beringin (Ficus benjamina), Tanjung (Mimusops elengi) yang memiliki ukuran tajuk 5 meter. Pohon Tanjung hanya terdapat 
tepat di depan hotel Shapir yang cukup tertata dan terawat. Permasalahan yang ditemui pada jalan ini juga sama dengan kedua jalan lainnya yaitu sebaran pohon tidak merata terutama pada bagian tepi jalan.

Secara keseluruhan jenis tanaman yang terdapat di masing-masing ruas jalan memiliki intensitas yang berbeda-beda. Faktor yang mempengaruhi perbedaan intensitas jalur hijau jalan adalah ketersediaan lahan yang ada, penggunaan tanaman, penataan tanaman dan perawatan tanaman. Jenis tanaman yang digunakan dalam elemen lanskap umumnya tanaman yang mampu mendukung aspek ekologis, fungsional dan memiliki nilai estetika tinggi.

\section{Komposisi Jalur Hijau Terhadap Penjerapan Pb}

Di Kota Yogyakarta pohon Angsana (Pterocarpus indicus) dan Tanjung (Mimusops elengi) merupakan jenis tanaman yang sering ditemukan di tiap-tiap ruas jalan kota. Berdasarkan penelitian Marlinda (2005), daun pohon Angsana mampu mereduksi Pb sebesar 5,95 ppm dan daun pohon Tanjung mampu mereduksi $\mathrm{Pb}$ sebesar 7,31 ppm. Jerapan $\mathrm{Pb}$ oleh pohon Angsana dan Tanjung berdasarkan jumlahnya di masing-masing jalan disajikan pada Tabel 5.

Tabel 5. Jerapan Pb oleh Pohon Angsana dan Tanjung Berdasarkan Jumlahnya Di Ruas Jalan

\begin{tabular}{lcccc}
\hline Nama Jalan & Jenis Tanaman & $\begin{array}{c}\text { Jumlah } \\
\text { Tanaman }\end{array}$ & $\begin{array}{c}\text { Jerapan } \mathrm{Pb} \times \\
\text { Jumlah tanaman }\end{array}$ & $\begin{array}{c}\text { Total jerapan } \\
\mathrm{Pb}(\mathrm{ppm})\end{array}$ \\
\hline KH. Ahmad Dahlan & Angsana & 72 & 428,4 & 428,4 \\
& Angsana & 43 & 255,85 & \\
Urip Sumoharjo & Tanjung & 35 & 255,85 & 511,7 \\
& Angsana & 65 & 386,75 & \\
Laksda Adisucipto & Tanjung & 10 & 73,1 & 459,85 \\
& & & & \\
\hline
\end{tabular}

Berdasarkan tabel 5, total jerapan $\mathrm{Pb}$ yang dihasilkan cukup tinggi yaitu sebesar 428,4 ppm untuk jalur hijau Jl. KH. Ahmad Dahlan, jalur hijau Jl. Urip Sumoharjo sebesar 511,7 ppm dan jalur hijau Jl. Laksda Adisucipto sebesar 459,85 ppm. Apabila jenis tanaman lain yang tersedia pada masing- masing ruas jalan ditambahkan, maka akan semakin tinggi pula jerapan $\mathrm{Pb}$ yang dihasilkan. Tetapi dari data kualitas udara ambien menunjukkan bahwa polutan jenis $\mathrm{Pb}$ sudah mendekati ambang batas yang ditentukan. Oleh karena itu dapat diasumsikan bahwa komposisi jalur hijau belum memadai.

Selain jumlah tanaman, kepadatan tajuk pohon juga mempengaruhi keefektifan penyaringan zat pencemar udara. Menurut Desianti (2011), tajuk yang rapat dan padat dapat menyerap polusi lebih baik dibanding tajuk yang terbuka. Semakin besar ukuran tajuk, semakin besar pula serapan dan jerapan polutan yang dihasilkan.

Ukuran tajuk rata-rata tanaman berukuran 3-8 meter di ketiga ruas jalan belum mampu menurunkan kadar $\mathrm{Pb}$ yang dihasilkan dari aktivitas lalu-lintas kendaraan bermotor. Rendahnya $\mathrm{Pb}$ yang terjerap oleh tajuk pohon dipengaruhi faktor kerapatan tanaman/jarak tanam dan ketersediaan tanaman yang tidak merata di sepanjang tiga ruas jalan. Selain kerapatan dan ukuran tajuk, jarak tanaman dari sumber emisi polutan juga sangat berpengaruh terhadap jerapan $\mathrm{Pb}$ yang dihasilkan. Jarak tanaman dari sumber emisi yakni $30 \mathrm{~cm}-2$ meter dari bahu jalan di ketiga ruas. Selain kerapatan dan ukuran tajuk, jarak tanaman dari sumber emisi polutan juga sangat berpengaruh terhadap jerapan $\mathrm{Pb}$ yang dihasilkan.

Jarak tanaman dari sumber emisi yakni 30 cm-2 meter dari bahu jalan di ketiga ruas jalan. Penempatan tanaman yang terlalu dekat dengan sumber emisi beresiko apabila polutan seperti $\mathrm{Pb}$ yang dihasilkan dari lalu-lintas kendaraan bermotor tinggi, maka akan bersifat toksit bagi tanaman. Penelitian Freer-Smith et al. (1997) cit. Hermawan 2011 menjelaskan bahwa debu ban- 
yak terakumulasi pada daun tanaman yang dekat dengan mobil. Hal ini dapat dijelaskan bahwa jarak tanaman dari sumber emisi yang berkisar antara $30 \mathrm{~cm}-2$ meter di masing-masing ruas jalan, $\mathrm{Pb}$ yang terjerap akan sangat tinggi. Akan tetapi dengan jumlah tanaman tergolong rendah, kerapatan tanaman rendah, penataan perawatan tanaman tidak maksimal, penggunaan tanaman belum menyesuaikan dengan kebutuhan jalan, ketersediaan lahan terbatas dan kepadatan lalulintas yang tinggi menyebabkan $\mathrm{Pb}$ pada udara ambien tidak terjerap maksimal dan terus meningkat jumlahnya di udara ambien.

Umur tambahan juga mempengaruhi akumulasi partikel timbal pada jaringan tumbuhan (Tung dan Temple, 1996 cit. Marlinda, 2005). Kondisi seperti ini ditemukan pada jalur hijau Jalan Laksda Adisucipto. Umur tanaman yang tergolong muda akan memiliki kerapatan tajuk yang juga rendah.,maka $\mathrm{Pb}$ yang terjerap oleh tanaman akan rendah.

\section{Evaluasi}

Permasalahan yang ditemukan di ketiga ruas jalan adalah rendahnya komposisi tanaman. Selain itu penataan dan perawatan tanaman di ketiga ruas jalan juga belum maksimal. Beberapa tanaman ditemukan rusak, telah digantikan tanaman lain, bahkan ditemukan mati. Komposisi tanaman pada ketiga ruas jalan masih dapat ditingkatkan mengingat ketersediaan lahan juga memungkinkan untuk pengembangan jalur hijau. Lahan yang tersedia adalah pada bagian trotoar. Pemilihan tanaman yang toleran terhadap berbagai jenis polutan merupakan salah satu bagian penataan jalur hijau jalan. Selain itu penataan tanaman sangat penting dilakukan untuk menyesuaikan dengan kebutuhan jalan yang dituangkan dalam model tata hijau jalur jalan. Adapun jenis tanaman yang direkomendasikan disajikan pada Tabel 6 .
Tabel 6. Jenis dan Fungsi Tanaman Rekomendasi

\begin{tabular}{|c|c|c|c|c|c|c|c|c|}
\hline \multirow{2}{*}{\multicolumn{2}{|c|}{ Jenis Tanaman }} & \multicolumn{7}{|c|}{ Menyerap Jenis Polutan } \\
\hline & & 1 & 3 & 4 & 5 & 6 & 7 & 8 \\
\hline Angsana & & $x$ & $x$ & $x$ & & & & \\
\hline Tanjung & & $x$ & $\mathrm{x}$ & $\mathrm{x}$ & & & & \\
\hline Palm kuning & & & & & $\mathrm{x}$ & $\mathrm{x}$ & $\mathrm{x}$ & $x$ \\
\hline Bougenvile & & $x$ & $x$ & $x$ & & & & \\
\hline Lidah mertua & & & & & $x$ & $x$ & $\mathrm{x}$ & \\
\hline Puring & & $\mathrm{x}$ & $x$ & $x$ & & & & \\
\hline Teh-tehan & & $x$ & $\mathrm{x}$ & $\mathrm{x}$ & & & & \\
\hline \multicolumn{9}{|c|}{ Sumber: Departemen Pekerjaan Umum (1999) dan Direktorat Jenderal Hortikultura (2012) } \\
\hline $\begin{array}{l}\text { Keterangan : } \\
\text { (1) CO } \\
\text { (2) Nox } \\
\text { (3) Sox }\end{array}$ & $\begin{array}{l}\text { (4) Pertikulat } \\
\text { (5) Benzena } \\
\text { (6) Formaldehid }\end{array}$ & $\begin{array}{l}\text { (7) Thricl } \\
\text { (8) Xylen } \\
\text { id }\end{array}$ & etilen & & & & & \\
\hline
\end{tabular}

\section{SIMPULAN}

1. Penggal Jl. Laksda Adisucipto Kota Yogyakarta diperlukan penataan ulang.

2. Jalan yang ditanami pohon Angsana (Pterocarpus indicus) dan Tanjung (Mimusops elengi) memiliki konsentrasi timbal $(\mathrm{Pb})$ lebih rendah yaitu sebesar $1,39 \mu \mathrm{g} / \mathrm{m} 3$ pada Jl. Urip Sumoharjo dan sebesar $1,11 \mu \mathrm{g} / \mathrm{m} 3$ pada Jl. Laksda Adisucipto dibanding dengan jalan yang hanya ditanami pohon Angsana (Pterocarpus indicus) yaitu Jl. KH. Ahmad Dahlan dengan konsentrasi $\mathrm{Pb}$ sebesar 1,56 $\mu \mathrm{g} / \mathrm{m} 3$.

3. Konsentrasi timbal $(\mathrm{Pb})$ di ketiga ruas jalan sudah mendekati nilai ambang batas, tetapi masih di bawah baku mutu yang ditentukan oleh pemerintah Provinsi Daerah Istimewa Yogyakarta.

\section{DAFTAR PUSTAKA}

Baiti, R. 2012. Pola Sebaran Ruang Terbuka Hijau di Kota Yogyakarta. Skripsi. Fakultas Pertanian. Universitas Muhammadiyah Yogyakarta.

BLH. 2012. Badan Lingkungan Hidup Kota Yogyakarta. Pemerintah Provinsi Daerah Istimewa Yogyakarta. Tidak di publikasikan.

.2013. Badan Lingkungan Hidup Kota Yogyakarta. Pemerintah Provinsi Daerah Istimewa Yogyakarta.

BPS. 2013. Kota Yogyakarta Dalam Angka 2013. Badan Pusat Statistik Kota Yogyakarta.

Departemen Pekerjaan Umum. 1999. Pedoman Pemilihan Tanaman Untuk Mereduksi Polusi (NOx, $\mathrm{CO}$ dan $\mathrm{SO}_{2}$ ). Yayasan Badan Penerbit Pekerjaan Umum. 
Desianti, A. 2011. Evaluasi Fungsi Ekologis Jalur hijau Jalan Kawasan Sentul City, Bogor. Departemen Arsitektur Lanskap. Fakultas Pertanian. Institut Pertanian Bogor.

Direktorat Jenderal Hortikultura. 2012. Tanaman Hias Potensil Menyerap Polutan. Direktorat Budidaya dan Pascapanen Florikultura.

Direktorat Jenderal Penataan Ruang. 2006. Ruang Terbuka Hijau Sebagai Unsur Utama Tata Ruang. Departemen Penataan Pekerjaan Umum. Jakarta.

Hermawan, R. 2011. Pengaruh Jumlah Baris Tanaman Jalur Hijau jalan Dalam Mereduksi Partikel Timbal (Pb) Dari Emisi Kendaraan Bermotor (Studi Kasus Jalur Hijau Acacia Mangium Jalan Tol Jagorawi). Departemen Arsitektur Lanskap. Fakultas Pertanian. Institut Pertanian Bogor.

Marlinda, N.S Rangkuti. 2005. Kemampuan Menjerap Timbel (Pb) Beberapa Jenis Tanaman Penghijauan di Jalan Tol Jagorawi: Analisis Struktur Anatomi dan Histokimia. Jurnal Analisis Lingkungan.

Pemerintah Republik Indonesia. 2007. Undang-Undang Nomor 26 Tahun 2007 Tentang Penataan Ruang.

2007. Keputusan Walikota Yogyakarta No. 619 Tahun 2007 Tentang Rencana Aksi Daerah Peningkatan Kualitas Lingkungan Kota Yogyakarta Tahun 2007-2011.

Rizka, J. 2009. Evaluasi Tata Hijau Jalur Hijau Jalan Kota Pekanbaru. Departemen Arsitektur Lanskap. Fakultas Pertanian. Institut Pertanian Bogor.

Samsoedin, I. 2010. Kajian Tingkat Toleransi Jenis-jenis Pohon Sebagai Penyerap dan Penjerap Polutan Timbal (Pb) dan Cd di Berbagai Tipe Curah Hujan. Badan Penelitian dan Pengembangan Kehutanan. Kementrian Kehutanan.

SLHD. 2012. Laporan Status Lingkungan Hidup Daerah. Pemerintah Kota Yogyakarta. Provinsi Daerah Istimewa Yogyakarta.

Sri Sultan HB X. 2002. Pencemaran Udara Yogyakarta Sudah Sampai Ambang Batas. http://www.suaramerdeka.com/harian/0211/27/dari 34.htm. Akses tanggal 09 April 2013.

Suparwoko dan F. Firdaus. 2007. Profil Pencemaran Udara Kawasan Perkotaan Yogyakarta: Studi Kasus Di Kawasan Malioboro, Kridosono, dan UGM Yogyakarta. Logika, Vol. 4, No. 2, Juli 2007.

Yulfida, Y. 2012. Perbandingan Kadar Karbon Monoksida (Co) Dan Nitrogen Dioksida $\left(\mathrm{NO}_{2}\right)$ Di Udara Ambien Berdasarkan Keberadaan Pohon Angsana (Pterocarpus Indicus) Di Beberapa Jalan Raya Di Kota Medan Tahun 2012. Program Sarjana Fakultas Kesehatan Masyarakat Universitas Sumatera Utara, Departemen Kesehatan Lingkungan. 
LAMPIRAN 1. Peta wilayah administrasi Kota Yogyakarta

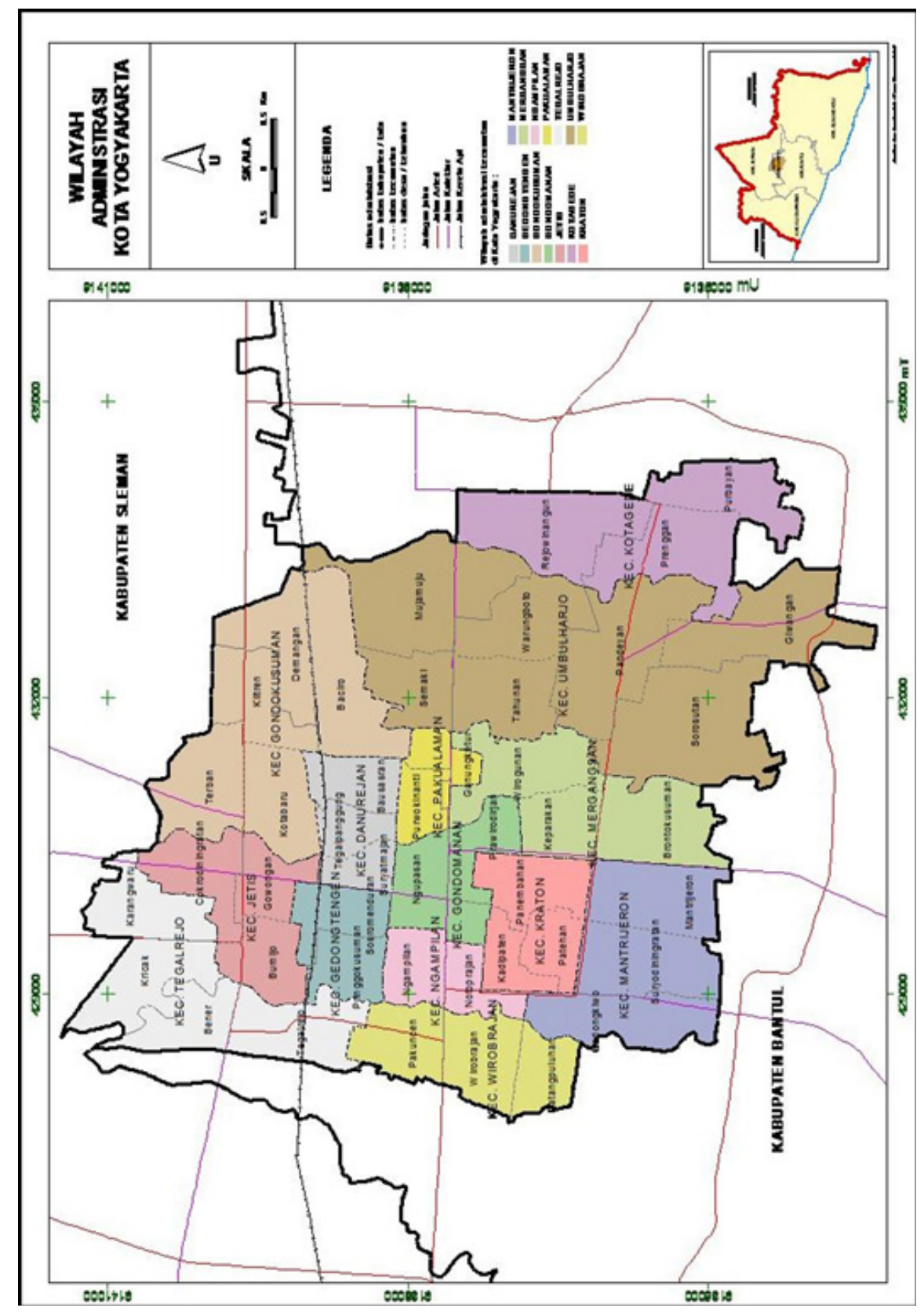


LAMPIRAN 2. Jenis tanaman yang terdapat di masing-masing lokasi

\begin{tabular}{|c|c|c|c|}
\hline Nama jalan & Nama tanaman & Ilmiah & Jenis tanaman \\
\hline \multirow{13}{*}{ KH. Ahmad Dahlan } & Adam hawa & Rhoeo discolor & Penutup tanah \\
\hline & Angsana & Pterocarpus indicus & Pohon \\
\hline & Antigonon & Antigonon leptosus & Semak merambat \\
\hline & Bakung & Russelia equisetiformis & Penutup tanah \\
\hline & Beringin & Ficus benjamina & Pohon \\
\hline & Bugenvil & Bougainvillea spectabilis & Perdu \\
\hline & Daun bahagia & Dieffenbachia sp & Semak \\
\hline & Kana & canna sp & Semak \\
\hline & Kersen/Talok & Muntingia calabura & Pohon \\
\hline & Ketapang & Terminalia catappa L & Pohon \\
\hline & Lidah mertua & Sansiviera & Penutup tanah \\
\hline & Palem kuning & Chrysalidocarpus lutescens & Semak \\
\hline & Teh-tehan & Acalypha Siamensis & Semak \\
\hline \multirow{14}{*}{ Urip Sumoharjo } & Anggur & Vitis vinifera & Semak merambat \\
\hline & Antigonon & Antigonon leptosus & Semak merambat \\
\hline & Angsana & Pterocarpus indicus & Pohon \\
\hline & Asem landi & Pitchecolobium dulce & Pohon \\
\hline & Beringin & Ficus benjamina $L$ & Pohon \\
\hline & Biola cantik & Ficus lyrata & Pohon \\
\hline & Bugenvil & Bougainvillea spectabilis & Perdu \\
\hline & Kamboja & Plumeria sp. & Perdu \\
\hline & Kiara payung & Filicium decipiens & Pohon \\
\hline & Lidah mertua & Sansiviera & Penutup tanah \\
\hline & Lili paris & Chlorophytum sp & Penutup tanah \\
\hline & Soka & Ixora coccinea $L$ & Perdu \\
\hline & Tanjung & Mimusops elengi & Pohon \\
\hline & Waru & Hibiscus tiliaceus & Pohon \\
\hline \multirow{10}{*}{ Laksda Adisucipto } & Angsana & Pterocarpus indicus & Pohon \\
\hline & Antigonon & Antigonon leptosus & Semak merambat \\
\hline & Bakung & Russelia equisetiformis & \begin{tabular}{|l|} 
Penutup tanah \\
\end{tabular} \\
\hline & Beringin & Ficus benjamina & Pohon \\
\hline & Lidah mertua & Sanseviera & Penutup tanah \\
\hline & Lili paris & Chlorophytum sp & Penutup tanah \\
\hline & Palem kuning & Chrysalidocarpus lutescens & Semak \\
\hline & Pucuk merah & Oleina syzygium & Perdu \\
\hline & Tanjung & Mimusops elengi & Pohon \\
\hline & Teh-tehan & Acalypha Siamensis & Semak \\
\hline
\end{tabular}

